\title{
Income Concentration and Its Impact on Economy and Society: The Case of Mexico
}

\author{
Carlos Encinas-Ferrer \\ Facultad de Negocios, Universidad De La Salle Bajío, León, México \\ Email: cencinas@delasalle.edu.mx
}

How to cite this paper: Encinas-Ferrer, C. (2017) Income Concentration and Its Impact on Economy and Society: The Case of Mexico. Modern Economy, 8, 211-231. https://doi.org/10.4236/me.2017.82015

Received: January 3, 2017

Accepted: February 17, 2017

Published: February 20, 2017

Copyright $\odot 2017$ by author and Scientific Research Publishing Inc. This work is licensed under the Creative Commons Attribution International License (CC BY 4.0).

http://creativecommons.org/licenses/by/4.0/

\begin{abstract}
As we move into the twenty-first century the problem that concentration and inequality in income distribution represent for the World is accentuated more and more. The great crisis of 2008 and its aftermath, the crisis in the Eurozone, took place due to a fall in aggregate demand. While the productive sector was working below its capacity, demand accumulated insufficiencies initiated years earlier. Since 1982 and the great crisis of external debt the neoliberal political system exacerbated the problem starting the dismantling of the welfare state based on the theories of John Maynard Keynes that had been built since the end of World War II. Neoliberalism disguised their ideology clearly in favor of the big transnational capital through developmentalist arguments unsubstantiated and that after nearly four decades of failure they refuse to recognize.
\end{abstract}

\section{Keywords}

Gross Domestic Product (GDP), Real GDP and GDP per Capita in Pesos and Dollars, Income Distribution, Income Concentration, Poverty, Domestic Market

\section{Introduction}

The lack of economic growth and the growing inequality in income distribution worldwide have become the most serious problems as we move into the twentyfirst century.

While inequality has existed historically and is intrinsic to the capitalist system of production, its most negative effects on economic performance had been curtailed by the economic policy instruments developed by John Maynard Keynes and other economists in the decades of the 30s and 40s of the twentieth century. By unemployment insurance, health and free public education, housing 
programs, direct transfers to the neediest, etc., the state could influence a better income distribution. This economic policy promoted the so-called "welfare state" and through it, wider and dynamic domestic markets and resources used return to enterprises producing goods and services through the sale thereof.

In the early eighties gain access to power political groups motivated by a school of thought that we know as neoliberalism, frontally opposed to any state intervention in the economy and that glorified the market as the perfect mechanism to allocate resources. It was a sector that had its origins in the most conservative interpretation of the neoclassical school which established their dominance over the teaching of the economy between 1880 and 1910 and lost influence during the decades of the twenties and thirties as a sequel of the First World War, the Mexican revolution, the Russian revolution and the great depression that began in 1929 and lasted until 1933. All these phenomena result of great contradictions within the productive system, opened the doors to the mainstream of economic thought called Keynesianism, inspired by the thoughts of the great English economist.

"After three decades in which income distribution had remained relatively stable, wages and incomes quickly became more unequal." [1] This problem has attracted my attention for several years. Product of this interest was the article I wrote in 2009 [2] in which I showed statistically that it was from 1980 that growing inequality began to spread in the United States. Remember that it was with the governments of Margaret Thatcher (1979-1990) in the UK, and Ronald Reagan (1981-1989) in the US that neoliberalism begins to spread virtually worldwide.

What do I mean by neoliberalism? I wrote some years ago [3], that I understand by neoliberalism the economic and political doctrine that uses a series of arguments of economic policy to impose as a paradigm the lack of state intervention in the economy and the disappearance of all transfer or subsidy that seeks to redistribute income among the population. Uses as its flag the free market (whatever that term means) as the only guarantee to achieve balance and economic growth. As an inherent contradiction of this doctrine, but as a logical result of its implementation, the beneficiaries of its measures have been transnational oligopolies and monopolies, natural enemies of free competition.

Neoliberalism has demonized the State pointing to him as terrible administrator but omitting something that is unquestionable: companies that show a shorter life are those created by private enterprise and the most catastrophic, bank and corporate bankruptcies, are found mostly among those in which the business sector dominates (Enron, American Home Mortgage, General Motors and Lehman Brothers are just a few examples to which we can add many more).

The rationalization provided by this political trend to justify the elimination of the welfare state is that entrepreneurs by accumulating wealth without tax limitations "drip" that wealth automatically to the lowest income sectors, the base of the pyramid. Reality has violated this interpretation of the "gravitational theory" of excess income since the same instead of falling have amounted to the 
tip of it, concentrating more and more.

One by one reality has been showing that these "new paradigms" were merely fallacies dressed in scientificists' costumes. In the UK, the real per capita income growth went from $2.37 \%$ annual average between 1960 and 1979, to 1.87\% from that date on. In US, real growth per capita fell from $2.87 \%$ annual average in the first period, to $1.64 \%$ from 1980 .

Despite these results and others, in recent years we have seen the one that I wish were the lash of a failed system, the imposition of austerity policies during the economic recession. In a desperate effort to stop the Keynesian expansionist policies, they have created a new scarecrow: public debt. No matter if Public Debt is equivalent to $48 \%$ of GDP (Mexico), 94\% (France), 78\% (Germany) or $105 \%$ (USA), you are forbidden to use fiscal policies.

In several countries of the "South" of Europe, such as Greece, three of the four variables of GDP: consumption, investment and foreign trade balance are in red numbers and government spending; the only one that could be increased to activate the aggregate demand has been cut off by Brussels imposed austerity.

The apologists of neoliberalism expect a miracle that makes, nevertheless, GDP to recover. Even they talk of a fifth element of GDP, unknown in the texts of our science, "restoring confidence" to bring back the solution to the problem of lack of demand. Who's confidence? Consumers' confidence? Industrial investors' confidence? Obviously not, the formers do not have enough income to recover and the industrial investors don't find consumers to whom sell their future production. Only we have the confidence of speculative capital, called "financial", but their owners no longer see anywhere how to obtain profits without producing, their favorite sport.

Although the issue of distribution of income among the population is becoming prominent object of study of global importance, in Mexico there has been paid little attention to it until recently. It was in the seventies, following concerns expressed by the World Bank on the problem of poverty that research focused on its measure began but it was until the eighties that we observed wide divergence of views and approaches that face results and interpretations about what poverty is.

It has not been until recently that the issue of income distribution and its concentration has begun to be addressed more broadly.

\section{Income Concentration}

When we refer to the concentration of income we do it to the way in which the national income accumulates in the hands of the richest population of a country. It implies in this case that regardless of whether an economy grows or not, as time goes on the wealth and income generated accumulates in a small number of its inhabitants. If the economy does not grow or does so at a slow pace, the percentage of the population in poverty increases. If the economy grows, most of that growth does not increase the purchasing power of the majority but concentrates in a few hands. 
Since economic growth implies a greater capacity of production, the present distribution of the income places us before a fundamental contradiction: the economic structure can produce more but the demand is prevented to grow in equal proportion. We are faced with an economy of waste.

This is a global phenomenon; it is giving both local and worldwide. It begins with the domination of neoliberal policies since 1980 and the implementation of its two main measures:

1) dismantling of the welfare state and

2) Global trade and financial liberalization.

The problems we are experiencing in the economic and social world and that neoliberal policies have worsened are found in the concentration of income and its sequel: the increasing poverty. My interest in its study coincided with that of many other scholars.

It is curious that politicians and thinkers of neoliberalism with its policies are undermining the functioning of its so highly praised market through measures that have generated marked impoverishment of the middle classes and increasing the population in poverty. The market needs of consumers, not just vendors, and by reducing demand, supply is underused. This is the basis of my hypothesis.

Over the past two years we have seen a large volume of research on our subject and its socioeconomic impact.

The Nobel Prize for Economics, Joseph Stiglitz, professor at Columbia University in New York, was in some ways a pioneer in the topic when publishing in 2012 his book "The Price of Inequality". Take his opinion on the impact of the concentration of income in the economic and social world expressed for OXFAM:

"The extreme inequalities in incomes and assets we see in much of the world today harm our economies, our societies, and undermine our politics. Whilst we should all worry about this it is of course the poorest who suffer most, experiencing not just vastly unequal outcomes in their lives, but vastly unequal opportunities too. Oxfam's report is a timely reminder that any real effort to end poverty has to confront the public policy choices that create and sustain inequality." [4]

Of great interest were the debates videotaped between him and the other Nobel Prize, Paul Krugman, in which Stiglitz masterfully maintained his view that the great financial crisis of 2008 had its origin in the concentration and inequality in income distribution. During the same we saw evolve markedly Krugman to the point that a year ago he resigned his professorship at Princeton to join the Luxembourg Income Study Center, institution specialized in the subject of this work which has a branch in the City of New York University (CUNY).

In 2013 the French economist Thomas Piketty public his book "Capital in the Twenty-First Century" [5] which addresses the issue. They have printed multiple editions in various languages. Work enthusiastically received among the public, but markedly among students of universities around the world. 
Most recently, in May 2016, Harvard University Press published the book "Global Inequality: A New Approach For The Age Of Globalisation" by Branko Milanovic [6], Senior Scholar at the Luxembourg Income Study Center, and Visiting Presidential Professor, Graduate Center, City University of new York (CUNY).

On May 15, 2016, the World Economic Association, of which I am a member, started the online seminar "Capital Accumulation, Production and Employment: Can We Bend the Arc of Global Capital Toward Justice" [7] which lasted from May 15 to July 15 and where issues that are part of this research were addressed.

\subsection{Extreme Inequality Hurts Everyone}

The rapid increase in economic inequality is a serious obstacle to both poverty eradication and for the distribution of prosperity.

The enormous productive capacity achieved by our society is underutilized because the increasing number of population in poverty prevents full use of it. The age of scarcity is over.

"It damages our ability to live within the planet's resources and succeed in the fight against climate change. It makes the struggle for equality between the sexes far harder." [8]

\subsection{An Economy at the Service of the $1 \%$}

The gap between rich and poor is reaching higher levels to the point that, for example, the international bank Credit Suisse published recently that the richest $0.7 \%$ of the world population has $45.2 \%$ of global wealth [9], and if we move to the $1 \%$, another $0.3 \%$, then they have more wealth than the remaining $99 \%$ [10]. In 2015 Oxfam predicted at the World Economic Forum in Davos this trend but data from the Swiss bank stepped forward one year that prediction. Wealth in the hands of the poorest half of humanity (3750 million in writing this) has been reduced by one trillion dollars over the past five years [9]. In the most recent Oxfam publication, An Economy for the 99\%: It's time to build a human economy that benefits everyone, not just the privileged few [11], show us "... that just eight men own the same wealth as the poorest half of the world. As growth benefits the richest, the rest of society-especially the poorest-suffers. The very design of our economies and the principles of our economics have taken us to this extreme, unsustainable and unjust point."

These figures are clear evidence that inequality in the world has reached unprecedented levels.

\section{Inequality and Concentration of Income in USA}

For the preparation of this section I used the statistical information provided by the United States Census Bureau [12] in its pages. Mainly the "Historical Income Tables: Households" [13] and among them "Table H-3. Mean Household In- 
come Received by Each Fifth and Top 5 Percent: all races" in the last-mentioned page.

For the per capita GDP figures I used in the "Historical Income Tables: People" [14] the "Table P-1. Total CPS Population and Per Capita Income: all races".

From 1950 to 1980 Keynesian policies and the welfare state that accompany them, managed to overcome the natural tendency to income concentration, typical of our economic system, but from 1981 with the coming to power of Ronald Reagan and its neoliberal team, inequality and income concentration rose again and ended up being restored at the previous levels from 2009 to date, these trends have been taking root as shown by the graphs presented below.

Change in trends when the neoliberal policies began to be applied is so clear that in several of the graphs I pointed out with a gray streak the year 1981 in which those policies took place.

From 1967 to 1981 the gap between the average income of the top 5\% of the population with higher incomes in relation to GDP per capita is reduced from 11.5 times higher to 8.86 but from 1981 starts increasing to stand in 2015 at 11 times (1100\%) more (Figure 1).

In the same period (1967-2015) the per capita income of the population with the lowest entries (Quintile 1) in relation to national per capita GDP was permanently reducing from $65 \%$ to $39 \%$, as shown in Figure 2. This means that the poorest $20 \%$ of the US population. (65 million inhabitants) has seen their income decrease permanently in relation to the national average income.

Figure 3 shows that in 1981 the average income of families in the richest 5\% of the US was 16.3 times higher than that of $20 \%$ of the lower income. From that year on, this relationship began to increase and by the year 2015 it was already 28.2 times greater.

Previous figures show best of all how income is being concentrated in the richest population of the US while economic growth is not reaching the poorest population that sees their share of GDP decline.

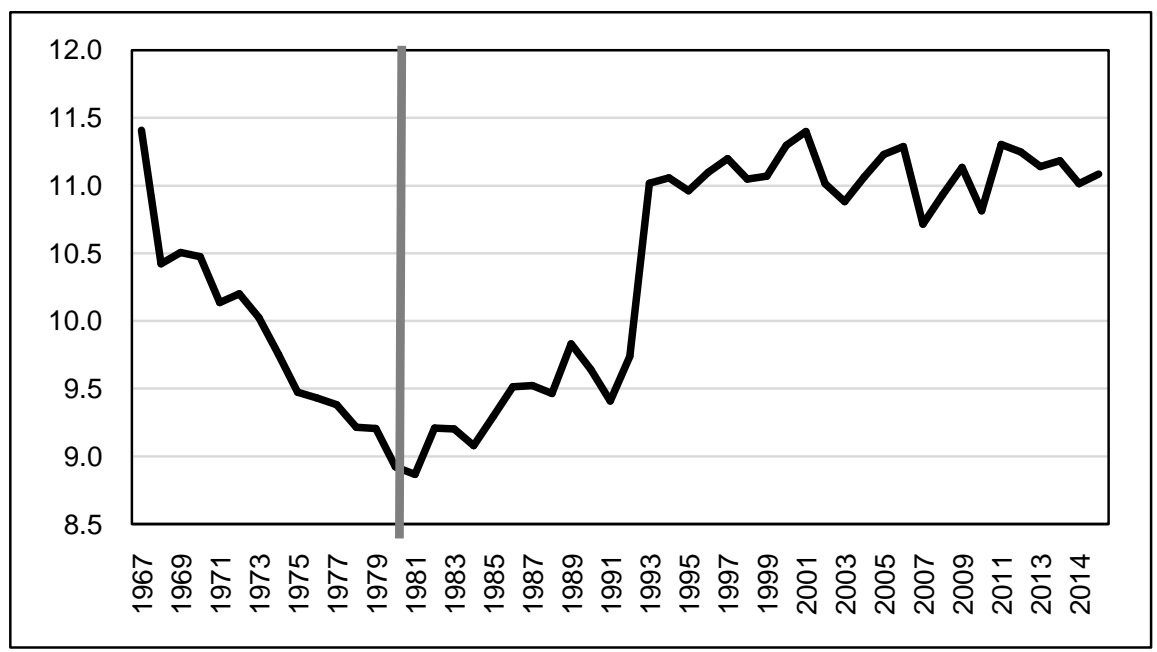

Figure 1. US higher 5\% income population/GDP per capita. Own elaboration with data from the US Census Bureau: Tables H-3 and P-1. 


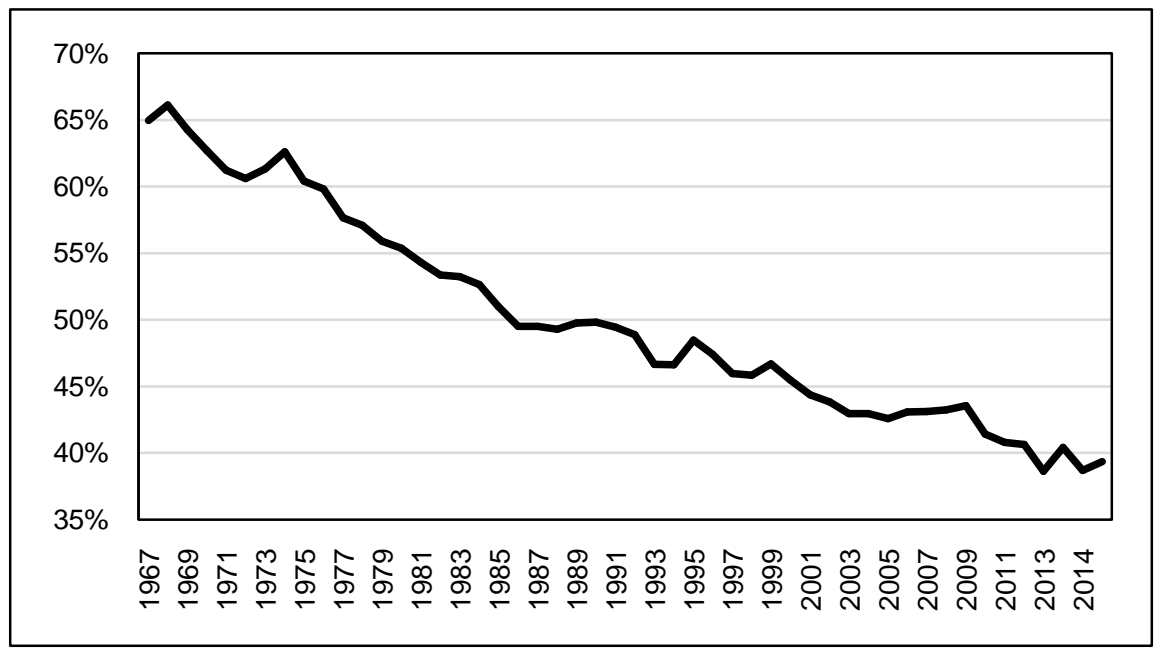

Figure 2. US lower income quintile/GDP per capita. Own elaboration with data from the US Census Bureau: Tables H-3 and P-1.

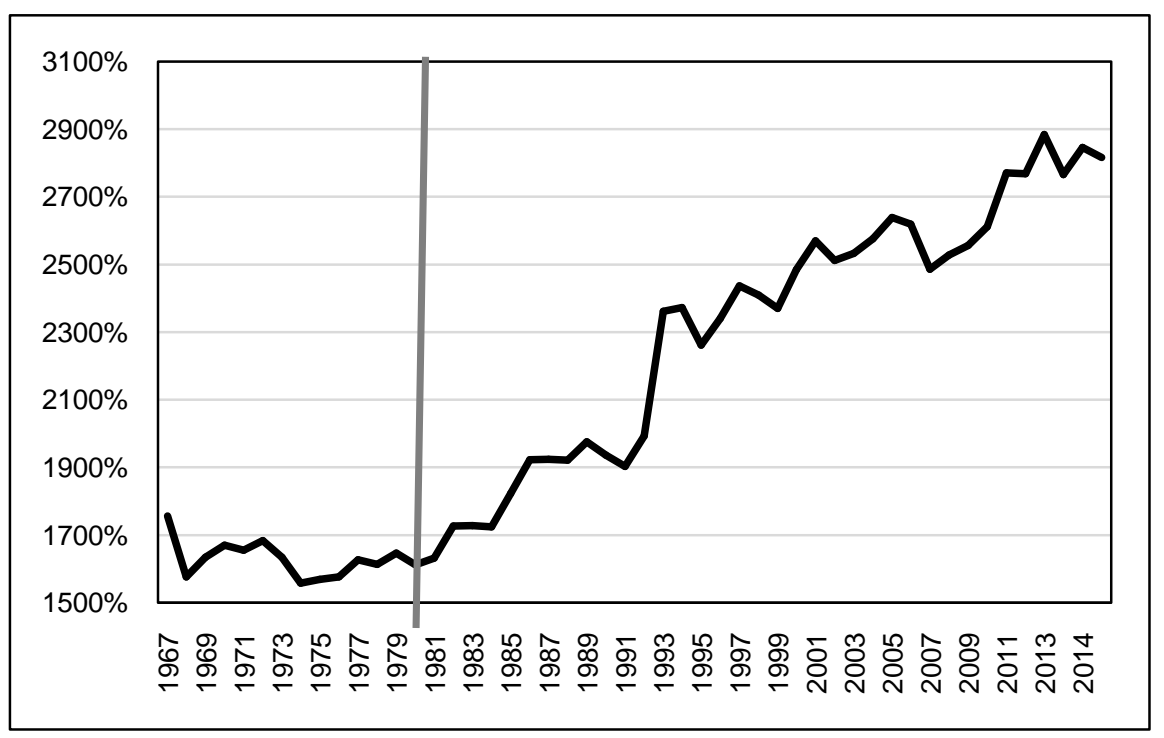

Figure 3. US $5^{\text {th }}$ percent of upper income/lower income quintile. Own elaboration with data from the US Census Bureau.

\section{Income Distribution in Mexico}

In the case of Mexico, we have seen published several papers on the issue of inequality but clearly focused on its relationship with poverty.

We can highlight, among others, studies regularly carried out by the National Council for Evaluation of Social Development Policy (CONEVAL). This organization measures different dimensions to calculate poverty [15];

1) Minimum welfare: monthly income per family member of at least $\$ 1242.61$ pesos in the urban environment and $\$ 868.25$ in rural;

2) Wellness: 2542.13 pesos (urban) and 1614.65 (rural);

3) Other: social deprivation at education, access to health services, access to social security, access to food, quality housing space, housing and basic services.

Moreover, the National Institute of Statistics and Geography (INEGI) [16] 
regularly publishes the National Survey of Income and Expenditures of Households (ENIGH) [17] that has allowed for years to approach to measuring differences in household income in our country.

The ENIGH has established the division of household income in deciles based on the average per each of the ten socioeconomic strata in which we divide the total per capita family average. Decile I correspond to $10 \%$ of lower income and $\mathrm{X}$ to the highest income.

Let's look at Figure 4 derived from this survey in 2014 [18]. It highlights the difference between decile IX and X, and the compaction in the first 9 deciles.

In 2015 INEGI did a unilateral review of ENIGH [19] without consulting CONAPO. In this review inhabitants belonging to the lowest income decile increased it above 30\%. INEGI argued that the figures obtained from the survey were underreported and that interviewers were trained to re-interview families in which there were clear indications of it.

It has been said that many families do not include transfers received from social programs in their response, but it should be remembered that ENIGH 2014 and earliest include a report with transfers and another without them.

The explanations given so far by INEGI question the randomness that should prevail in any survey.

This increase did not help improving the face of poverty in our country at international levels because the strong depreciation of our currency maintained our GDP per capita practically without change when measured in 2016 dollars.

\subsection{The State of Knowledge}

The most complete work up to date in relation to the concentration of income in our country was written by Raymundo M. Campos Vazquez, Emmanuel S. Chavez Jimenez and Gerardo Esquivel Hernandez (2014) and entitled "High Income,

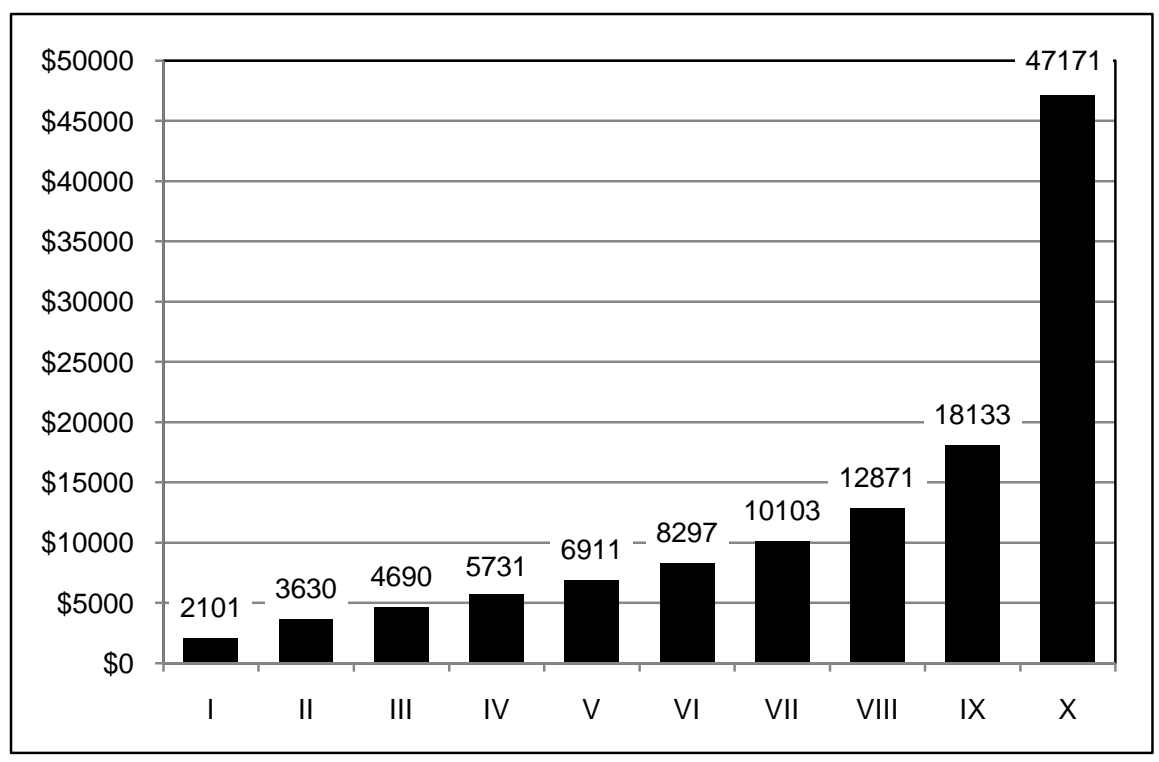

Figure 4. Mexico: Annual per family income by deciles in U.S. Dollars. Own elaboration with data from INEGI (ENIGH 2014). 
Optimal Taxation and Possible Revenue." [20] In this paper the authors through a rigorous analysis worked with the differences between the ENIGH and data provided by the National Accounts. However they use the same proportion of household income over national disposable income which is very low from my point of view in comparison with other countries statistics.

His first result tells us that participation in the total income of the richest $1 \%$ of individuals in Mexico is $21.3 \%$. "Moreover, the average annual income of individuals in the highest $0.01 \%$ of the distribution is around 30.5 million pesos". This paper allows us to see inside the $\mathrm{X}$ decile with more detail.

Of great importance is the work done by Gerardo Esquivel under the sponsorship of Oxfam Mexico, and entitled "Extreme inequality in Mexico" [21]. In that writing, Esquivel extends beyond mere poverty to give us an overview of its opposite, the vast wealth accumulated at the highest levels of the last decile.

Araceli Damian and Julio Boltvinik, meanwhile, presented their work "Evolution of poverty and social stratification in Mexico 2012-2014. Integrated Method of Measurement of Poverty and Social Stratification (MMIPE)” [22]. Applying this method, they come to a stunning conclusion: $90 \%$ of the population of our country is at some level of poverty. From this we can immediately deduce the following conclusion: that a country of almost 130 million inhabitants, like ours, is reduced to a "modern and dynamic" market of only 13 million (3.3 million families). A poor internal market incapable of being by itself the engine of our economy!

\subsection{Inequality in Mexico Is Worse than Thought, INEGI}

Alfredo Bustos and Gerardo Leyva in 2016 [23], researchers in the General Office of Research of INEGI, adjusted ENIGH data with administrative records of the Tax Administration Service (SAT).

This harmonization shows that the inequality in income is greater than what INEGI traditionally reports every two years when published in ENIGH.

Bustos and Leyva point out that while per the data of the ENIGH survey, the richest $10 \%$ of the families would accumulate $34.89 \%$ of the national income, deciles VI to IX $44.66 \%$ and deciles I to V $20.45 \%$, applying the harmonization brought out by them the numbers change significantly: decile $\mathrm{X}$ yields $50.2 \%$ of the total income, deciles VI to IX $37.93 \%$ and deciles I to V only $11.87 \%$.

Our authors based their study on two assumptions:

1) The real income of households in the survey is higher than what respondents report (what researchers call "underreporting"), so the income poverty seems more than real, as households whose real incomes are above the poverty line are considered to be in poverty, and

2) Households with much higher revenues than those reported by respondents and are included in the sample ENIGH do not appear in it (what Bustos and Leyva called "truncation"). Therefore, inequality appears underestimated, in relying solely on ENIGH, since the difference between high-income and small income will be lower than the real one. 
In Figure 5, we observe how the picture changes when we remove the inconsistencies between the ENIGH and SAT.

\subsection{ENIGH Survey Modified}

The 2015 Socioeconomic Conditions Module (MCS 2015) [24] was picked up what is known as ENIGH 2015 during the period from August 11 to November 28, 2015. On August 8, 2016, the basic tabulation files and statistical precisions were replaced.

The statistical information covers the year 2015 and is the one I used in the estimates that we will see below.

\section{Own Estimates of the Income Distribution}

Given the fact that in every survey respondents tend to hide information and that especially happens in the high-income levels, I followed the previous works but adjusting upward the income of households since the reported is markedly below the net national income. Therefore, I have adjusted it according to the percentages that are found internationally in other countries in which there is less tax evasion and, therefore, a greater tax collection.

As I mentioned previously, I will start my estimations from the last ENIGH modified, corresponding to data from 2015 [25]. I will assume that the subaccount in the income of the Decile I has been corrected.

The ENIGH 2015 is based on an estimated population of 121,525,893 and $33,218,037$ families, which gives us an average of 3.6584 inhabitants per family.

The total income of the families in the survey is US $\$ 384,570,608,368$ and this is where the divergence is found with my estimate of household income. Per the

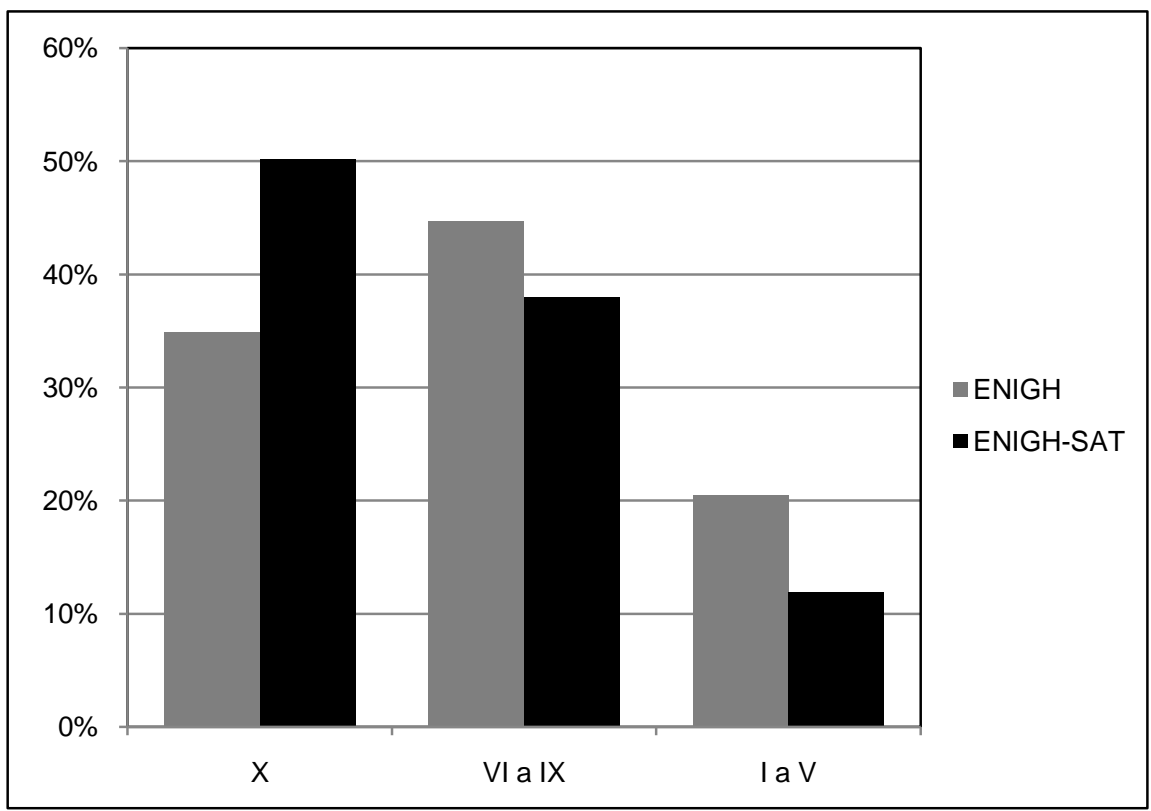

Figure 5. Mexico: change in the percentage participation of the deciles according to ENIGH and according to ENIGH-SAT. Own elaboration with data from INEGI (ENIGH 2014) and Leyva and Bustos. 
Adjusted Net National Income (aNNI) definition [26] the same is obtained by subtracting to GDP the net taxes $(\mathrm{T})$ and the Consumption of Fixed Capital (CFC) and the depleted natural resources, and adding the net foreign factor income (NFFI).

In my estimation, I subtracted from the 2015 GDP at market prices [27], US $\$ 1,143,369,270,424$, taxes paid that year, US $\$ 148,934,489,961$, my estimate of fixed capital consumption (FCC), US $\$ 12,059,914,140$, and I added the net factorial inflows, US $\$-34,125,041,194$. This gave me as Adjusted Net National Income (aNNI) the amount of US $\$ 948,249,825,128$ which is consistent with the estimations of the Adjusted Net National Income by The World Bank.

Given the difference between household income (HI) and my aNNI estimate for Mexico, I went on to a comparative analysis of the estimate of income per deciles in other countries [28] relative to their own aNNI figures and I calculated the index obtained by dividing them.

In 2014 this coefficient in Mexico (ENIGH 2014) was 36.11\% while in Costa Rica was 74.14\% [29] and in US 63.86\%. In the case of ENIGH 2015 the percentage was increased to $41.61 \%$ in relation to my aNNI estimates. I do not know the reason why in our country traditionally the income of families has been calculated so much below the aNNI but I believe that tax evasion, not only because of the size of the informal economy, but because of the non-declaration of total income in the richest strata-which Bustos and Leyva call truncation-has prevented us from having a clear idea of the magnitude of the income inequality in our country.

As I said before, if we take for good that the modifications in the ENIGH 2015 allowed to correct the sub report in Decil I, in this study I will try to go further in the knowledge of the income distribution in Deciles IX and X.

When analyzing the US figures in World Bank Data and the Census Bureau, in 2014 I observed that aNNI was US $\$ 14,941,050,770,221$ and the HI US $\$ 9,540,685,568,000$, equivalent to $63.9 \%$ of the first. This percentage is close to that of the United Kingdom and Germany. The average percentage of aNNI of those countries with respect to family income is $62.1 \%$, coefficient that I took in this study to obtain the income of the households and that serves as a basis for my calculations: US $\$ 596,352,348,108$, amount greater than $\$ 384,570,608,369$ of ENIGH 2015.

Campos, Chávez and Esquivel (2014) point out that there is a high level of income concealment in the higher income groups, which does not appear in the SAT figures due to tax evasion. Therefore, after adjusting the AHI/NNI coefficient to the US, UK and Germany average (62.1\%), I applied like Campos, Chavez and Esquivel (2014) - in Column 4 of his writing-the amount thus increased to deciles IX (20\%) and to X (80\%), which our authors consider the most adequate distribution.

Our authors calculated that $1 \%$ of the population with the highest income in our country gets $21.3 \%$ of total income, $0.1 \% 8.3 \%$ and $0.01 \% 3.3 \%$. These figures allowed me to generate Table 1 as well as my analysis inside the Decile $\mathrm{X}$ 
(Table 2 and Figure 6).

Taking the Campos, Chavez and Esquivel (2014) estimates of income distribution at the $1 \%, 0.1 \%$, and $0.01 \%$ of the families in Mexico belonging to decile X, I built Figure 6 with my estimate data about the AHI. Amounts refer to the annual household income in US dollars. We see how income distribution concentration continues inside Decile X.

\section{The Causes of Income Concentration}

In all the estimates I have presented, we clearly observe the high concentration of income that has been given in Mexico.

We should not look for the cause of the concentration of income in the lack of growth of our economy. It has been given at the expense of the labor factor. During the past years, this relation has been clearly unfavorable to the second one (Samaniego 2014) [30] as we observe in Figure 7.

Table 1. Mexico: Distribution of household incomeby deciles.

\begin{tabular}{ccccc}
\hline Decile & Household income & Families & Average income & $\%$ \\
\hline I & $6,846,623,413$ & $3,321,804$ & $\$ 2061$ & $1.16 \%$ \\
II & $11,590,393,895$ & $3,321,804$ & $\$ 3489$ & $1.97 \%$ \\
III & $15,410,161,860$ & $3,321,804$ & $\$ 4639$ & $2.62 \%$ \\
V & $19,399,383,133$ & $3,321,804$ & $\$ 5840$ & $3.29 \%$ \\
VI & $23,867,072,777$ & $3,321,804$ & $\$ 7185$ & $4.05 \%$ \\
VII & $29,220,762,400$ & $3,321,804$ & $\$ 8797$ & $4.96 \%$ \\
VIII & $36,063,133,383$ & $3,321,804$ & $\$ 10,856$ & $6.12 \%$ \\
IX & $45,372,847,681$ & $3,321,804$ & $\$ 13,659$ & $7.71 \%$ \\
X & $102,250,016,226$ & $3,321,804$ & $\$ 30,781$ & $17.36 \%$ \\
Total & $298,841,851,171$ & $3,321,804$ & $\$ 89,963$ & $50.75 \%$ \\
\hline
\end{tabular}

Source: own elaboration on data of INEGI, Bank of Mexico, Index Mundi and author's review. In U.S. Dollars.

Table 2. Mexico: Distribution of household income inside Decile X.

\begin{tabular}{cccc}
\hline$\%$ & Household income & Families & $\begin{array}{c}\text { Average income per } \\
\text { household }\end{array}$ \\
\hline $9.00 \%$ & $173,414,192,790$ & $2,989,623$ & $\$ 58,005$ \\
$0.90 \%$ & $76,552,091,969$ & 298,962 & $\$ 256,059$ \\
$0.09 \%$ & $29,443,112,296$ & 29,896 & $\$ 984,844$ \\
$0.01 \%$ & $19,432,454,115$ & 3322 & $\$ 5,849,971$ \\
$10.00 \%$ & $298,841,851,171$ & $3,321,804$ & $\$ 89,964$ \\
\hline
\end{tabular}

Source: own elaboration on data of INEGI, Bank of Mexico, Index Mundi and author's review. In U.S. Dollars. 


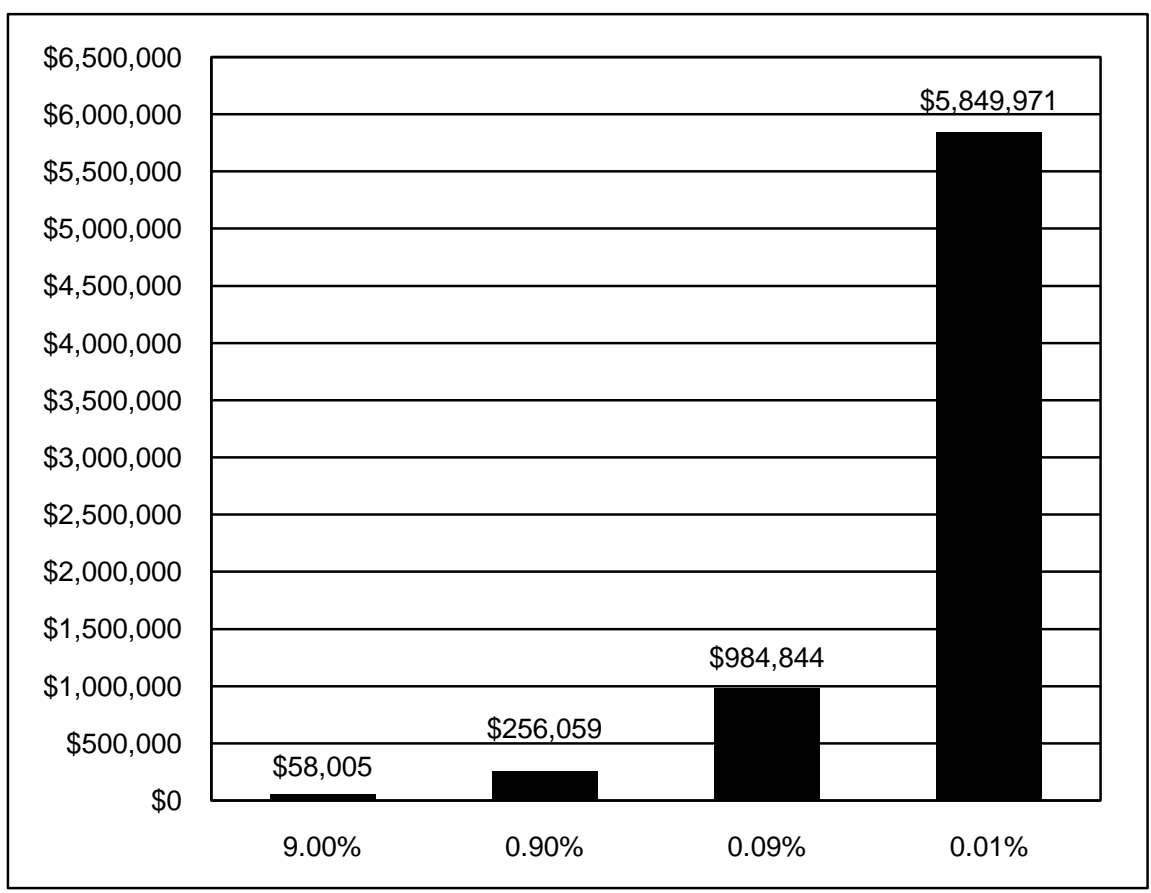

Figure 6. Mexico: 2015 annual per family income inside Decil X in current U.S. Dollars. Own elaboration with my own estimates using Campos, Chavez and Esquivel (2014) tables.

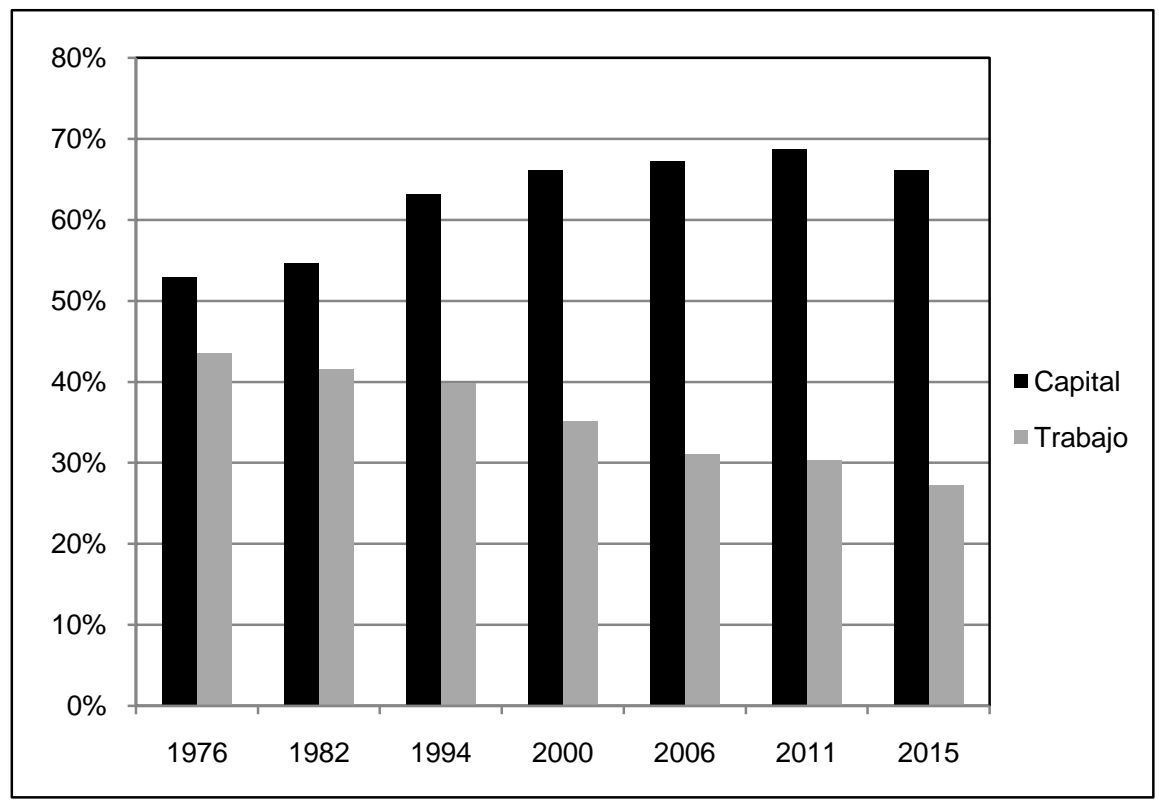

Figure 7. Distribution of available national income. Own elaboration with data from INEGI.

\section{Productivity and Income Concentration. Are Both Correlated?}

During this research, I have found clear evidence that there is a relation between the increase in productivity generated by the technological revolution and the concentration of income. This warrants further research beyond what I am currently presenting. 
This is logical, since the technological revolution has increased the automation of both the productive processes and the services sector. This has occurred to such a degree that it has been accompanied by the extent of unemployment in an economic system lacking a Sector 4 that could absorb it. Recall that in the eighteenth and nineteenth centuries, during the industrial revolution, unemployment in Sector 1, mainly agriculture and livestock, was absorbed by the growth of Sector 2, the manufacturing one. In the second half of the twentieth century automation was extended to industrial processes generating a growing unemployment that was absorbed by Sector 3, that of services. However, in the late twentieth century and markedly in the first years of XXI technological development has led also to the automation of Sector 3 and a rising unemployment that cannot be absorbed by a nonexistent Sector 4, sector that could only work outside the capitalist laws of market.

The publication in June 2016 of the Penn World Table, Version 9.0 [31], has forced me to reconstruct this part of my research. PWT 9.0 provides us with up-to-date information until 2014 and a comprehensive review of variables that are critical to this writing.

The inferences that can be deduced from the information presented by PWT 9.0 are important. Below we see a fundamental graph to understand how the increase in productivity has not permeated the labor factor and if it has accumulated in the capital factor.

In Figure 8 we see that in 1981 productivity in Mexico reached its highest historical value, \$19.34 per hour worked (measured in constant US \$ PPP 2005). It is also the year in which wages have the greatest purchasing power in our country. Productivity peaked in 1997 at $\$ 12.21$ an hour. From that date, it recovers and in 2014 it reaches $\$ 17.71$ an hour.

Taking the data on Total Factor Productivity (TFP), we see how the neoliberal economic policies in force since 1983 have been fundamental to understanding

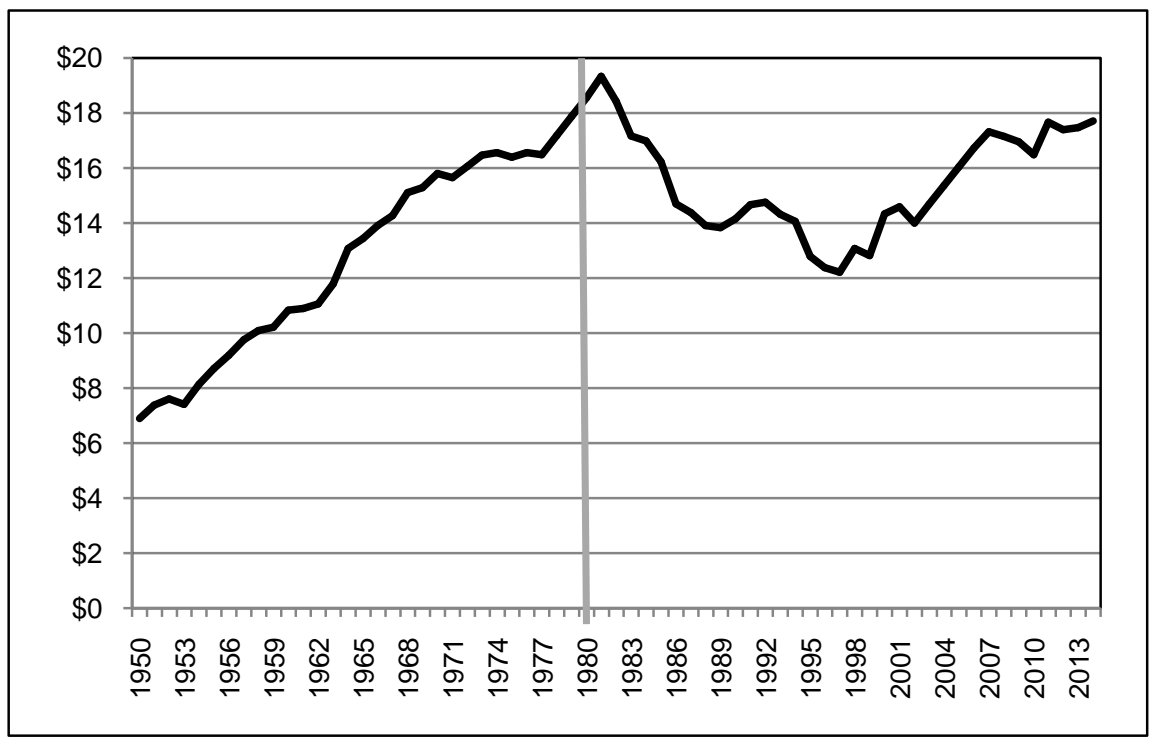

Figure 8. Mexico: Productivity per person employed (US Dollars PPP 2005). 
the lack of economic growth. Graph 19 shows that the TFP measured at national constant prices based on $2011=100$ went from $89 \%$ in 1950 to $153 \%$ in 1981 . From the debt crisis unleashed in 1982, the total productivity of the Factors falls, being 98.3\% in the year 2014 (Figure 9).

In Figure 10 we see the evolution of the Mexican TFP compared to that of the US measured in PPP Dollars at current prices. The total productivity was in 1950 equivalent to $82 \%$ of US. During the years of the so-called Stabilization Development (1958-1970), it rose $22.7 \%$ above that of the USA. But since 1982, with the crisis of the external debt and coinciding with the application of neoliberal policies, it falls rapidly and in 1989 represents only $76.8 \%$ of that of the United States.

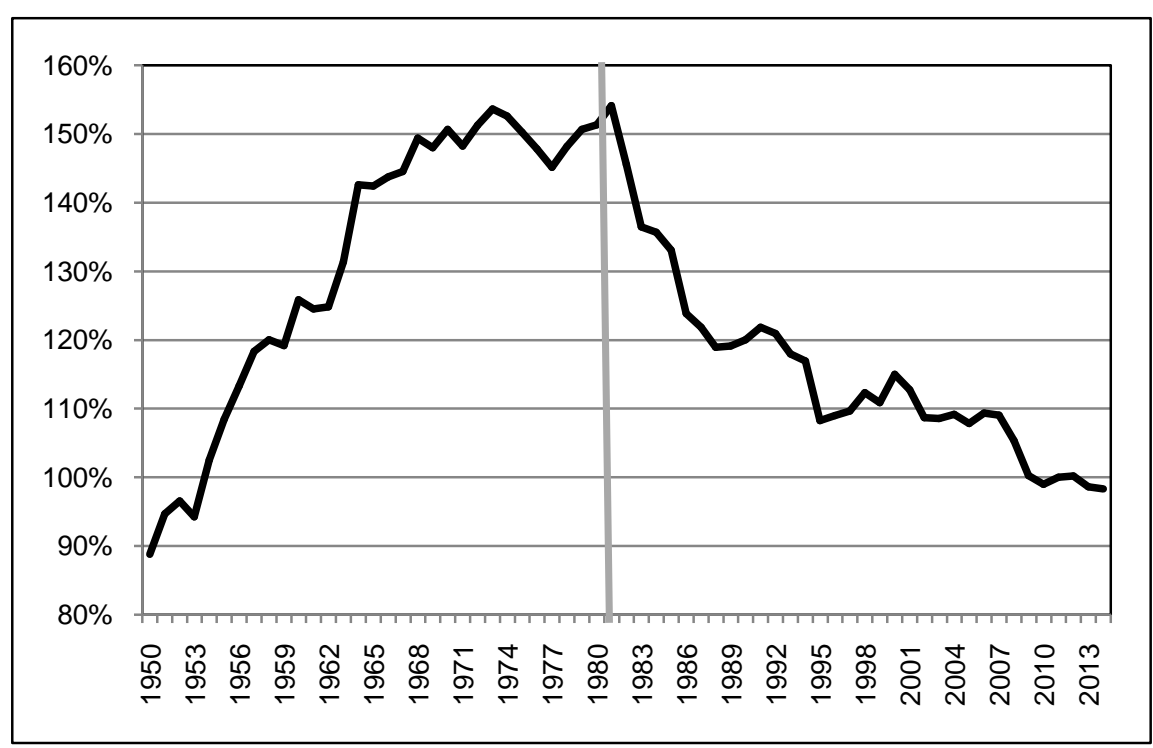

Figure 9. Mexico: Total factor productivity at national constant prices (2011).

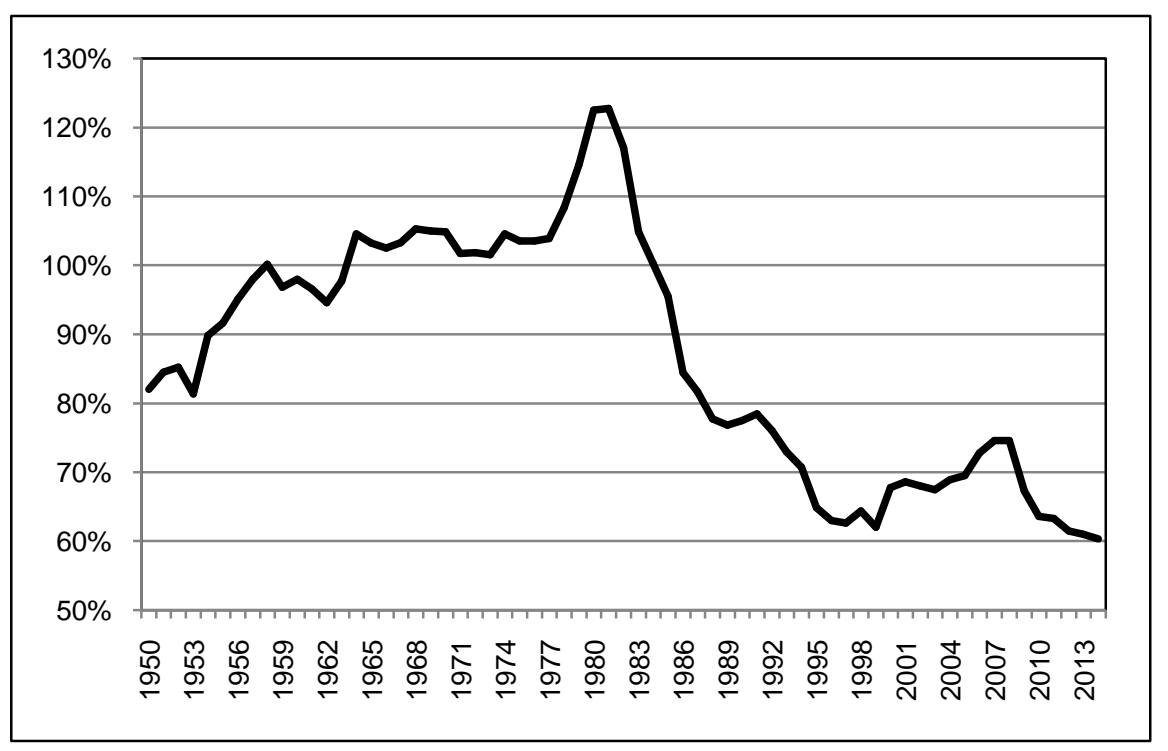

Figure 10. Mexico total factor productivity $(\mathrm{US}=100)$. Own elaboration with data from PWT 9.0. 
Trade and financial openness, including the alienation of banking, further leads the total productivity that comes in 1999 to represent only $62 \%$ of the US TFP. From 2000 we see a slight recovery that raises the TFP to $74.6 \%$ but with the crisis of 2008 the collapse of economy accelerates and in 2014 represents $60.3 \%$, a fall of $20 \%$ compared to 1950 and of $62.4 \%$ regarding to 1981 .

In Figure 11 we observe that from 2008 (base year $=100$ ) to date the labor productivity index has increased $8 \%$ while the wage index after falling $9 \%$ has recovered but remains almost the same as 2008 . The increase in productivity has gone to the hands of capital. That is why it is absurd to argue that the minimum wage could only be increased if productivity grows. The increase is in sight and therefore it is now time to increase remuneration and augment the purchasing power of the domestic market. Recall that any growth in wages returns to companies in the form of increased purchases.

However, the picture is worse if we take as the second variable the real unit cost of labor as we see in Figure 12. Productivity growth is accompanied by a reduction in the cost of labor as a percentage of the cost of the final product.

\section{Internal Market and Income Concentration}

One practical way I have used on several occasions to measure the size of the domestic market is to add exports (X) and imports (M) and divide them by GDP. This comparison of the size of our foreign trade with that of the national GDP gives us a very clear idea of the dependence of an economy on the foreign market. Obviously, another important variable is the Balance of Trade; if it is customarily negative (Mexico) we will have a small value-added output and the dependence will undermine the growth capacity of the national economy. If it is positive (Holland) the effect will be the opposite. I will use that coefficient in the following pages.

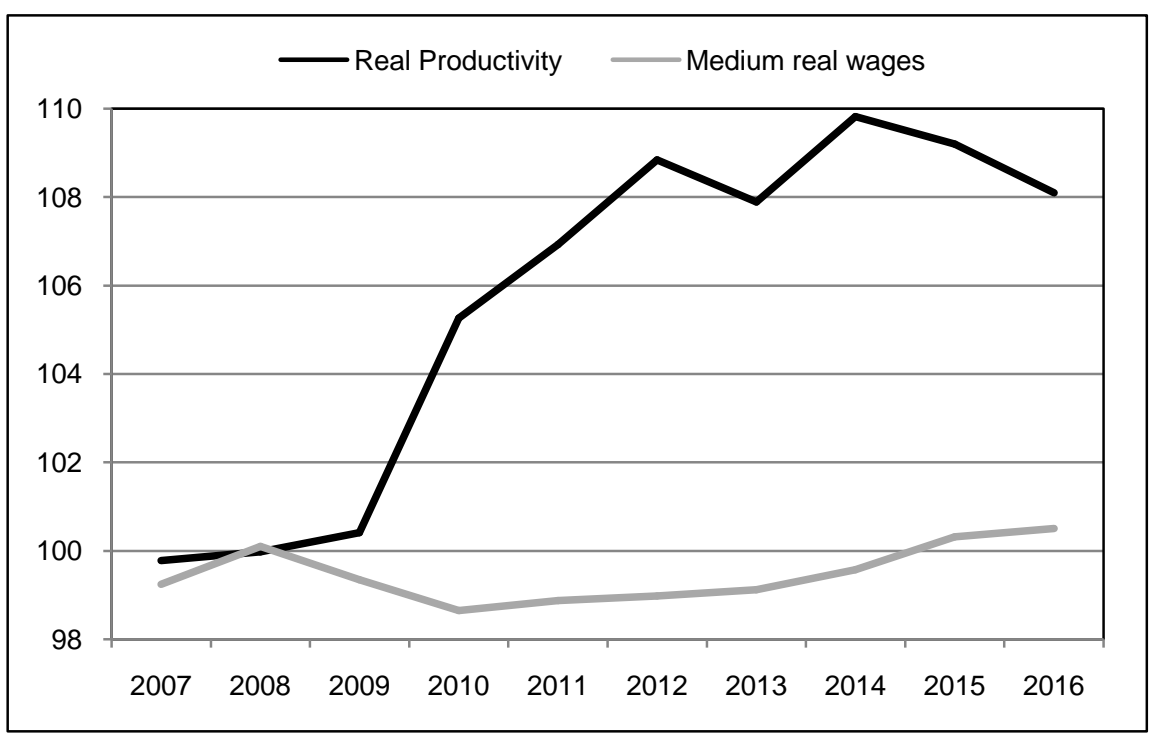

Figure 11. Mexico: Evolution of productivity and the real cost of labor $(2008=100)$. Own elaboration with Data from INEGI. 


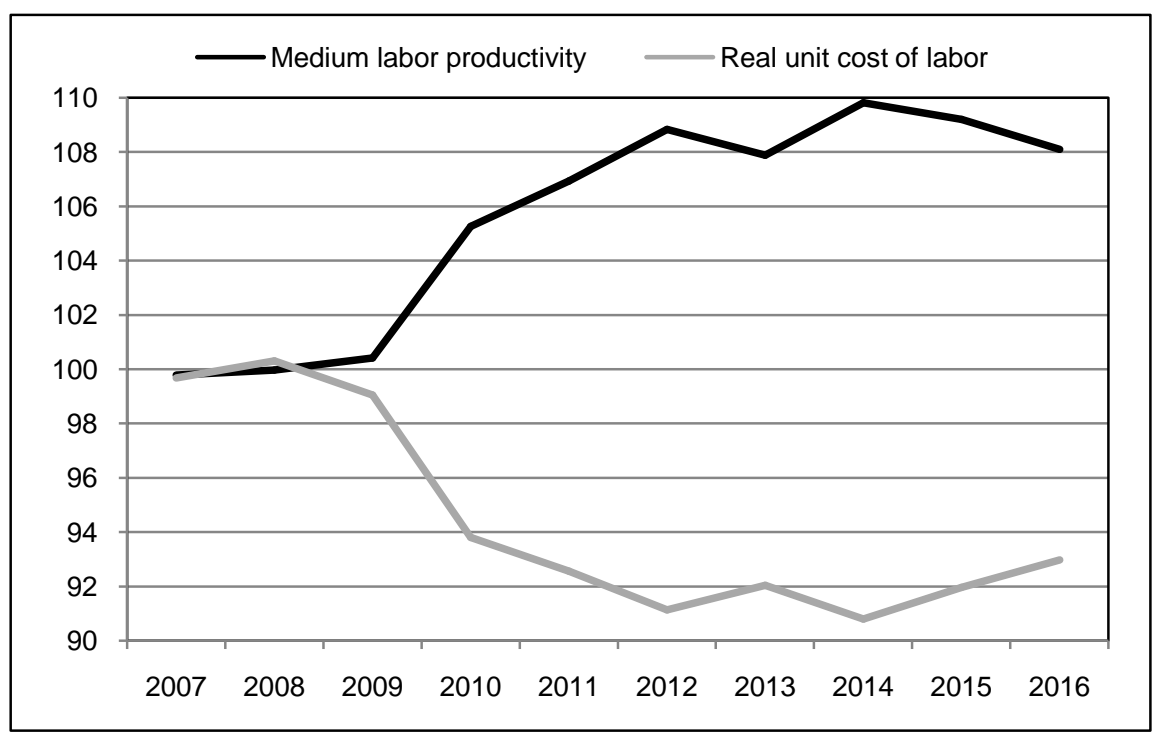

Figure 12. Mexico: Medium labor productivity and real unit cost of labor $(2008=100)$. Own elaboration with Data from INEGI.

Figure 13 shows the evolution since 1960 of the coefficient (X + M)/GDP for three significant countries. In the case of the USA we see that this ratio has decreased from $90 \%$ to $70 \%$ over the last 45 years, which gives us a clear idea of the weight that the domestic market has in our neighbor of the North, regardless of the commercial opening. In the case of China, the coefficient is lower than that of the USA until 1982 to fall to $30 \%$ of its GDP in 2006 and since that date, the year of the beginning of the high growth rate of recent times in that country, the weight of the domestic market rises to $60 \%$ of national GDP. This change makes China more independent from the foreign markets.

In the case of Mexico (Figure 13 and Figure 14), we observe that during the years of the so-called Stabilizing Development (1958-1970) [32] the domestic market represented more than $80 \%$ of GDP. After the crisis of 1982-1987 the coefficient falls to $62 \%$. It recovers reaching $75 \%$ in 1993 but from the great commercial opening of that year it falls abruptly and continues that fall until our days in which the weight of the internal market within our economy represents only $27.2 \%$. If we add to the above the permanent deterioration of the balance of our external trade that has accumulated a deficit during these 46 years of US $\$-203,699,508,265$, we will understand our lack of economic growth and how vulnerable we are to external shocks.

\section{Conclusions}

The studies by Campos et al. (2014), Bustos and Leyva (2016), as well as my own one, show that income inequality in Mexico is worse than what official figures have shown.

The richest $10 \%$ of the population (Decile $\mathrm{X}$ ) concentrates more than $50 \%$ of all income of Mexican families.

The difference between the first two investigations and my estimate is found 


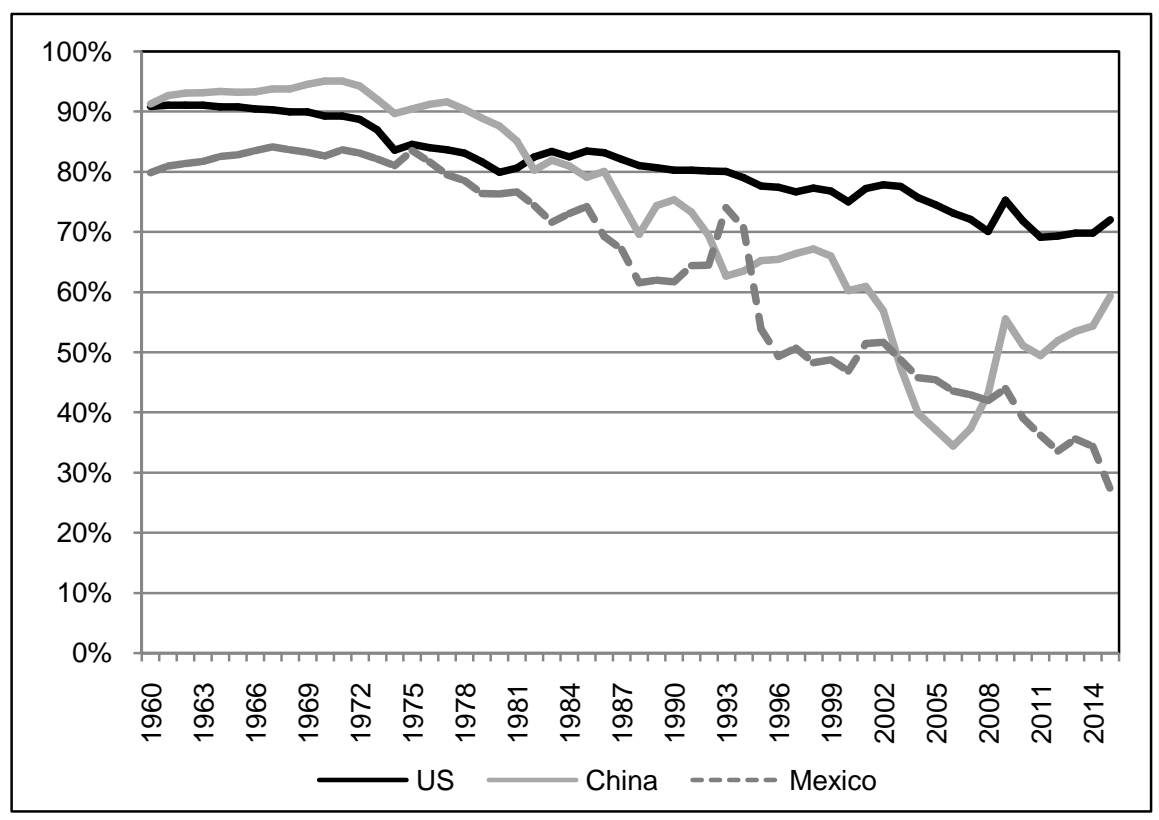

Figure 13. $(\mathrm{X}+\mathrm{M}) / \mathrm{GDP}$ coefficient of US, China and Mexico. Own elaboration with Data from World Bank [33].



Figure 14. Mexico: Evolution of the coefficient $(\mathrm{X}+\mathrm{M}) / \mathrm{GDP}$. Own elaboration with data from The World Bank.

in the percentage of income that corresponds to the lowest 10\% (Decil I), not so in their monetary income, which is $\$ 2061$ per year per family, which was equivalent in 2015 to a daily income per person in that decile of US \$1.54. In January 2017 with the depreciation of the Mexican Peso in that month would be equivalent to US $\$ 1.11$.

If from those figures, we subtract the "... imputed income called the rent of the $d$ welling and which represents little more than a fifth of the total household income of the decile I (21.5\%)" [34], daily net income would be US \$1.11 and US 
$\$ 0.87$ respectively: extreme poverty!

If we add the income corresponding to Deciles I to VIII- $80 \%$ of the population of Mexico-with an average exchange rate of 15.8542 pesos per US dollar in 2015 , the average daily income per inhabitant of the great majority of our population was US $\$ 5.29$ (US $\$ 3.81$ at the exchange rate of 22.00 pesos per US dollar). Insufficient income to sustain a demand for goods and services in an efficient market.

There is no doubt that the concentration of income and the reduced internal market are related and it is also true that the independent variable must be the first and not the other way around.

When the concentration of income occurs in a society dominated by low incomes among most of the population, its internal market is extremely weak and incapable of being the engine of its economy as we have seen previously.

Years ago, I read in an Italian magazine that we must be very careful when interpreting the statistical numbers as in the case, for example, that there are two people and a chicken on an island; statistically each islander would be accounted half a chicken but we do not know whether one of them owns the animal and eats it alone.

We already have international consensus that there has been an increase in inequality in most countries during the last decades and therefore a rise of poverty. The logical question that we should make us now is: What is the situation in Mexico?

In this paper we observe that in Mexico there is a huge concentration of income in a very small percentage of the population, while in the rest there is an extensive poverty and a reduced middle class. The number of inhabitants with an income capable of moving the domestic market is small and this has led to foreign trade representing such a high percentage of GDP.

The labor productivity in Mexico compared to its cost is enormous, which has prevented the increasing production of manufacturing from translating into higher incomes for the population.

This great dependence of the Mexican economy on international trade shows that the trade liberalization model adopted since 1993 is approaching its exhaustion and must be replaced by another that gives greater weight to the development of its domestic economy.

\section{References}

[1] Krugman, P. (1992) The Rich, the Right, and the Facts: Deconstructing the Income Distribution Debate. The American Prospect.

http://prospect.org/article/rich-right-and-facts-deconstructing-inequality-debate

[2] Encinas-Ferrer, C. (2009) Neoliberalismo y distribución del ingreso en los Estados Unidos de América. Problemas del Desarrollo, Revista Latinoamericana de Economía, Vol. 49, No. 158. Instituto de Investigaciones Económicas, UNAM. México.

[3] Ferrer, C.E., Guzmán, G.R. and Morales, L.I.R. (2008) Un planeta y cuatro o cinco mundos: La polarización económica y su impacto en el empleo. Los Rostros de la Pobreza, El Debate, Tomo V, Coord. Rocío Enríquez Rosas, Sistema Universitario 
Jesuita, Guadalajara.

[4] Oxfam (2014) Even It up, Time to End Extreme Inequality. Oxfam GB for Oxfam International under. United Kingdom.

[5] Piketty, T. (2014) El Capital en el Siglo XXI. Fondo de Cultura Económica, México.

[6] Milanovic, B. (2016) Global Inequality: A New Approach for the Age of Globalisation. Harvard University Press, EE.UU.

[7] Packer, A. (2016) Can We Bend the Arc of Global Capital toward Justice by Investment in Human Capital? World Economics Association (WEA) Conferences, No. 1 2016, Capital Accumulation, Production and Employment, 15th May to 15th July 2016.

http://capital2016.weaconferences.net/papers/can-we-bend-the-arc-of-global-capita l-toward-justice-by-investment-in-human-capital/http://capital2016.weaconference s.net/papers/can-we-bend-the-arc-of-global-capital-toward-justice-by-investment-i n-human-capital/

[8] Oxfam México.

http://www.oxfammexico.org/wp-content/uploads/2016/01/bp210-economy-one-pe rcent-tax-havens-180116-es.pdf

[9] Credit Suisse, Research Institute (2015) Global Wealth Report 2015.

https://publications.credit-suisse.com/tasks/render/file/?fileID=F2425415-DCA7-80 B8-EAD989AF9341D47E

[10] Credit Suisse (2016) Global Wealth Databook 2016. http://publications.credit-suisse.com/tasks/render/file/index.cfm?fileid=AD6F2B43B17B-345E-E20A1A254A3E24A5

[11] Oxfam International (2016) An Economy for the 99\%, Oxfam Briefing Paper, January 2017. https://www.oxfam.org/en/research/economy-99

[12] U.S. Census Bureau, Current Population Survey, Annual Social and Economic Supplements. https://www.census.gov/did/www/saipe/data/model/info/cpsasec.html

[13] U.S. Census Bureau, Historical Income Tables: Households. https://www.census.gov/data/tables/time-series/demo/income-poverty/historical-in come-households.html

[14] U.S. Census Bureau, Historical Income Tables, Table P-1. Total CPS Population and Per Capita Income: All Races.

https://www.census.gov/data/tables/time-series/demo/income-poverty/historical-in come-people.html

[15] Consejo Nacional de Evaluación de la Política de Desarrollo Social (CONEVAL) Medición de Pobreza.

http://www.coneval.org.mx/Medicion/Paginas/PobrezaInicio.aspx

[16] Instituto Nacional de Estadística y Geografía (INEGI) Sistema de Cuentas Nacionales de México, SCNM. Instituto Nacional de Estadística y Geografía. Banco de Información económica (BIE). http://www.inegi.org.mx/sistemas/bie/

[17] Instituto Nacional de Estadística y Geografía (INEGI) Encuesta Nacional de Ingresos y Gastos de los Hogares (ENIGH). http://www.inegi.org.mx/est/contenidos/proyectos/encuestas/hogares/default.aspx

[18] Módulo de Condiciones Socioeconómicas de la ENIGH (MCS-ENIGH) 2014. www.beta.inegi.org.mx/proyectos/enchogares/modulos/mcs/2014/

[19] Módulo de Condiciones Socioeconómicas de la ENIGH (MCS-ENIGH) 2015. www.beta.inegi.org.mx/proyectos/enchogares/especiales/mcs/2015/

[20] Campos, V., Raymundo, M., Emmanuel, S., Chávez, J. and Gerardo, E.H. (2014) Los Ingresos Altos, la Tributación Óptima y la Recaudación Posible. Premio Nacional 
de Finanzas Públicas. Centro de Estudios de las Finanzas Públicas, Cámara de Diputados, H. Congreso de la Unión. México.

[21] Esquivel, G. (2015) Desigualdad Extrema en México, Concentración del Poder Económico y Político. Iguales, Oxfam, México.

http://www.cambialasreglas.org/pdf/desigualdadextrema informe.pdf

[22] Damián, A. and Julio, B. (2015) Evolución de la pobreza y la estratificación social en México 2012-2014. Método de Medición Integrada de la Pobreza y la Estratificación Social (MMIPE). México.

http://www.julioboltvinik.org/images/stories/pobreza\%20presentacin\%20de\%20res ultados\%202014\%20conferencia\%20de\%20prensa.pdf

[23] Bustos, A. and Gerardo, L. (2016) Hacia una estimación más realista de la distribución del Ingreso en México. Revista Este País. Tendencias y Opiniones. México.

http://www.estepais.com/articulo.php?id=hacia-una-estimacion-mas-realista-de-ladistribucion-del-ingreso-en-mexico1

[24] Instituto Nacional de Estadística y Geografía (INEGI) Encuesta Nacional de Ingresos y Gastos de los Hogares (ENIGH).

http://www.beta.inegi.org.mx/proyectos/enchogares/especiales/mcs/2015/

[25] INEGI. Módulo de Condiciones Socioeconómicas (MCS) 2015. Precisiones estadísticas. 2016.

http://www.beta.inegi.org.mx/proyectos/enchogares/especiales/mcs/2015/

[26] World Bank (2011) The Changing Wealth of Nations: Measuring Sustainable Development in the New Millennium.

http://siteresources.worldbank.org/ENVIRONMENT/Resources/ChangingWealthN ations.pdf

[27] Banco de México. Estadísticas. http://www.banxico.org.mx/estadisticas/index.html

[28] Milanovic, B.L. and Yitzhaki, S. (2016) Decomposing World Income Distribution Database. The World Bank, Data and Research, Research at the World.

http://econ.worldbank.org/WBSITE/EXTERNAL/EXTDEC/EXTRESEARCH/0, con tentMDK:20713100 pagePK:64214825 piPK:64214943 theSitePK:469382,00.html

[29] Costa Rica, Instituto Nacional de Estadística y Censos, Encuesta Nacional de Ingreso y Gasto de los Hogares (ENAHO) 2015.

http://www.inec.go.cr/ingresos-y-gastos-de-hogares/ingresos-de-los-hogares

[30] Samaniego Breach, Norma (2014) La participación del trabajo en el ingreso nacional: El regreso a un tema olvidado. CEPAL, Estudios y Perspectivas, Noviembre 2014, México. http://repositorio.cepal.org/bitstream/handle/11362/37279/1/S1420829 es.pdf

[31] PWT 9.0 de la Universidad de Groningen, Holanda. http://www.rug.nl/research/ggdc/data/pwt/pwt-9.0

[32] Antonio, O.M. (1998) El Desarrollo Estabilizador: Reflexiones sobre una época. Fondo de Cultura Económica y El Colegio de México, México.

[33] The World Bank. Data. http://datos.bancomundial.org

[34] Rogelio, G.H. (2016) Setenta pesos al día para 3.3 millones de hogares. http://frentealapobreza.mx/setenta-pesos-al-dia-3-3-millones-hogares/ 